\title{
GRADIENT METAMORPHISM, ZONAL WEAKENING OF THE SNOW-PACK AND AVALANGHE INITIATION
}

\author{
By C. C. Bradley, R. L. Brown and T. R. Williams \\ (Department of Civil Engineering and Engineering Mechanics, College of Engineering, \\ Montana State University, Bozeman, Montana 597 I5, U.S.A.)
}

\begin{abstract}
A co-ordinated study involving both a field investigation in Yellowstone National Park and a laboratory investigation was undertaken to evaluate the process of temperature-gradient metamorphism on the mechanical properties of snow. Both parts of the investigation showed that, when subjected to a negative temperature gradient, low-to-medium density snow metamorphoses first into a fine-grained anhedral depth hoar before finally acquiring a fully developed, and stronger, euhedral crystal structure. Measurements indicated that the subhedral snow was the weakest stage in the metamorphic process and that, while strength may drop to as low as 10\% of the original strength, the material stiffness decreased by less than $50 \%$ Also, it was observed that the location of weakest snow was usually the point of a local maximum density and largest temperature gradient, thus suggesting a relationship between metamorphic state and thermal conductivity.
\end{abstract}

RÉsumÉ. Métamorphose de gradient, affaiblissement localisé du manteau neigeux et departs d'avalanches. Une étude concertée comprenant des observations de terrain dans Yellowstone National Park et une recherche en laboratoire ont été entreprise; pour estimer l'influence du métamorphisme de gradient thermique sur les propriétés mécaniques de la neige. Les deux parties de cette recherche ont montré que, lorsqu'elle est soumise à un gradient de température négatif, la neige de densité faible ou moyenne se transforme d'abord en un givre de profondeur irrégulier à grains fins avant d'acquérir finalement une structure pleinement développée de gros cristaux réguliers. Des mesures indiquent que la neige au stade intermédiaire était la plus fragile dans le processus de la métamorphose et que, alors que la résistance peut descendre jusqu'à $10 \%$ de la résistance initiale, la densité matérielle décroît de moins de $50 \%$. Aussi on observe que l'emplacement de la neige la moins solide était d'habitude le point de densité locale maximum et de plus fort gradient de température, ce qui suggère une relation entre le stade de la métamorphose et la conductivité thermique.

Zusammenfasiung. Temperatur-Metamorphose, zonale Schwächung der Schneedecke und Lawinenauslösung. Zum Studium der Veränderungen der mechanischen Eigenschaften des Schnees unter einem Temperaturgradienten wurde eine koordinierte Untersuchung, bestehend aus Feldbeobachtungen im Yellowstone National Park sowie aus Laborversuchen, vorgenommen. Beide Teiluntersuchungen zeigten, dass Schnee von geringer bis mittlerer Dichte unter dem Einfluss eines negativen Temperaturgradienten sich zuerst in feinkörnigen anhedralen Tiefenreif verwandelt, bevor er endgültig eine vollentwickelte festere euhedrale Kristallstruktur annimmt. Messungen wiesen darauf hin, dass der subhedrale Schnee das schwächste Stadium im metamorphen Prozess darstellt, und dass die Materialsteife um weniger als $50 \%$ abnahm, während die Festigkeit bis auf $10 \%$ der ursprünglichen Festigkeit sinken kann. Ebenso wurde beobachtet, dass an der Stelle des nachgiebigsten Schnees gewöhnlich ein lokales Dichtemaximum und der höchste Temperaturgradient herrschte. Dies lässt eine Beziehung zwischen dem Stadium der Metamorphose und der Wärmeleitfähigkeit vermuten.

\section{INTRODUGTION}

The formation of a fragile basal layer of metamorphosed snow has long been considered to be a primary source of snow avalanches. Seligman (1936) credits Paulcke as being the first to make the association of depth hoar with avalanches. Since that time it has been fairly well understood that both a negative temperature gradient and a sufficient porosity to allow a vapor flux are needed for the formation of depth hoar.

During the I96o's, there was renewed interest in depth hoar and its relationship to avalanche occurrence. Bradley ( 1966 ) proposed that climax avalanches may be initiated as the result of compressive failure of a weak basal layer followed by collapse of the overlying slab. This concept of a weak layer was further verified by Bradley and Bowles (1967) when these investigators formulated a stability index in terms of a strength-to-load ratio for the snow-pack. The correlation between this ratio and the probability of snow-pack collapse and/or avalanche occurrence suggests that depth-hoar collapse may indeed play a central role in the initiation of many avalanches.

Probably because of the close association between avalanches and crystalline depth hoar, avalanche lore has tended to lean toward the notion that the more perfect the crystal development, the greater the threat. 
Much research on this topic has centered around the investigation of depth hoar and its physical and mechanical characteristics. Some excellent studies of depth hoar have been made by the Japanese, in particular Kojima (r956) and Akitaya (r965, r967[a], r967[b], 1974). The last of Akitaya's works was particularly good, as this paper defined the conditions under which the depth-hoar structure can be formed, the rate at which depth hoar develops, and the physical process responsible for its formation.

Many field observations by Bradley (1968), in studies which involved the use of a resistograph to measure snow strength, raised a question concerning depth hoar. When strength as measured by the resistograph was compared with crystal stratification, the weakest zone was more often found to be a subhedral layer above the fully-developed euhedral depth hoar. As a consequence it was suspected that the weak link might not be the euhedral zone but the snow that was still metamorphosing into depth hoar.

The purpose of this study is to answer the above question and to investigate the process of temperature-gradient metamorphism and its effect on strength, density, and the other mechanical properties. To accomplish this, a co-ordinated laboratory and field study was undertaken to make a detailed investigation. The site chosen for the field study was the Old Faithful area of Yellowstone National Park, since this is a geothermal area which provides a constant supply of heat to the snow-pack all winter long. This, in effect, eliminates one problem of a non-constant heat source, thereby making a parametric study of the problem somewhat easier. In conjunction with this, a laboratory study was conducted with the intent of growing depth hoar under controlled conditions, thereby allowing a check of the field results.

\section{FIELD STUDY}

As mentioned above, the Old Faithful site was chosen because the area acts as a constant heat source throughout the winter. In addition, the cold climate combined with a lowdensity snow-pack acts to produce a collapsing snow virtually every winter. Three thermistor stacks were installed in a radial line from the Old Faithful vent. In each stack, two thermistors were buried, one at a depth of $250 \mathrm{~mm}$ and the other at $100 \mathrm{~mm}$. In this way the temporal and spatial character of the heat flux into the snow from the ground could be observed. The three stacks were placed at intervals of $6 \mathrm{~m}$ at a sufficient distance from the vent (approximately $30 \mathrm{~m}$ ) to ensure that they would be covered by a good depth of snow. In Figures I and 2 the locations of the three stacks are indicated by stations I, 2 and 3 where station 3 is the farthest from the Old Faithful vent. The temperature regimen in the snow-pack was

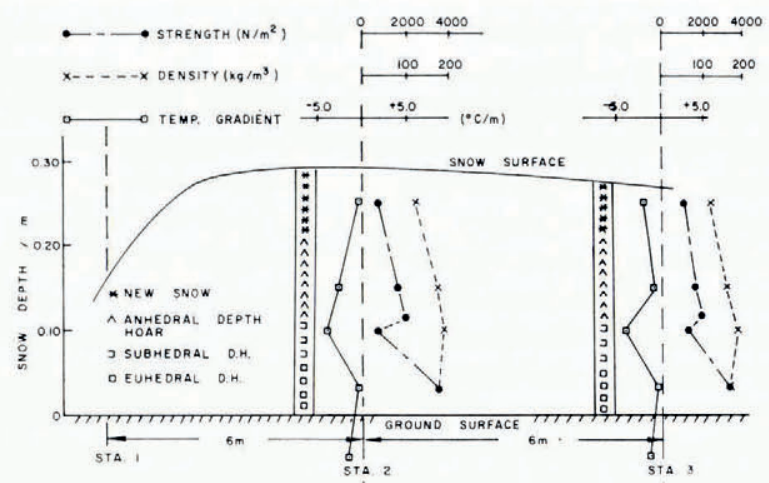

Fig. I. Vertical distribution of density, temperature gradient, and strength at Yellowstone, test on I4 December I974. 
measured by means of a thermistor probe with a resolution of \pm 0.2 deg., so that a detailed record of the temperature from the air through the pack to $250 \mathrm{~mm}$ below the ground level could be observed.

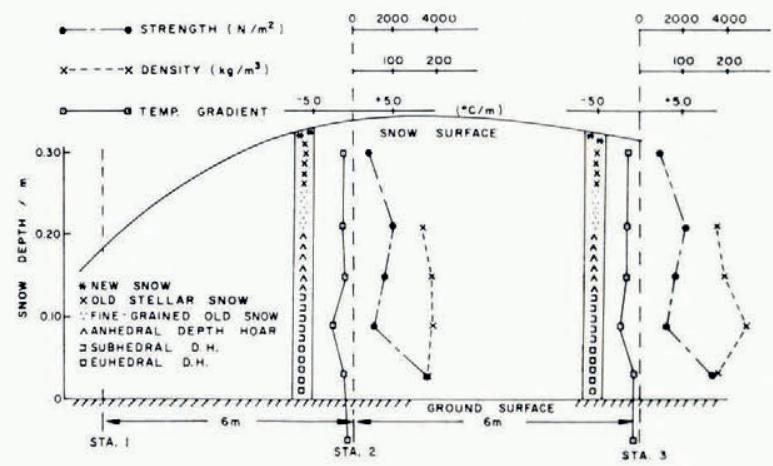

Fig. 2. Vertical distribution of density, temperature gradient, and strength at Yellowstone, test on 18 December 1974.

Meteorological observations were made on a daily basis. They included the minimum and maximum temperatures, the snowfall, and the snow accumulation on the ground. In addition, frequent resistometer readings were made to record snow strength. The resistometer is a probe with a conical point and a spring-mounted handle coupled with a sensitive displacement dial indicator. It is capable of giving accurate spot strength measurements of very weak snow at depth. Finally, snow-pit studies were conducted in regular intervals at all three stations. In these studies the crystal stratification was recorded photographically, density measurements and whisk-broom abrasion tests were made, and the snow strength profile was measured with a resistograph. The information obtained from data collected by these measurements was then used to study the development of euhedral depth hoar and the variation of the mechanical and physical properties of the snow.

Figures I through 4 illustrate results of the field investigation. Figures 1 and 2 contain data actually recorded at stations I, 2 and 3 plus information gathered from the pit studies. Station I, as it turned out, was located too close to the Old Faithful vent, and consequently it was never covered by a snow-pack of any significant depth. Therefore, no useful data were obtained from that station.

Generally, Yellowstone National Park receives an abundant amount of snow during December. However, in 1974, snowfall was below average and, as can be observed in Figures $\mathrm{I}$ and 2, the snow-pack did not exceed a depth of $0.40 \mathrm{~m}$ during that month. This relatively shallow pack plus the cold weather and steady heat flux from the ground resulted in copious amounts of depth hoar. Therefore, the investigators had ample opportunity carefully to study the process of temperature-gradient metamorphism under field conditions.

The depth hoar was classified into three subgroups: euhedral, subhedral and anhedral. Euhedral depth hoar consists of a large, fully-developed skeletal structure containing cupshaped crystals, plates, sheaths, and needles. This is a large crystal structure (approximately $2 \mathrm{~mm}$ ) with an unmistakable character. The subhedral depth hoar is similar to euhedral depth hoar but is not so fully developed. The grains are smaller ( $\mathrm{mm}$ to $2 \mathrm{~mm}$ ) with some solid crystal structure and an abundance of plates and sheaths but with little cup construction. The anhedral snow is essentially depth hoar of a solid type with a small, solid crystal structure having flat surfaces and sharp corners. It shows the effects of temperaturegradient metamorphism, but there is no skeletal development, and the crystals generally are no longer than $\mathrm{I} \mathrm{mm}$. 

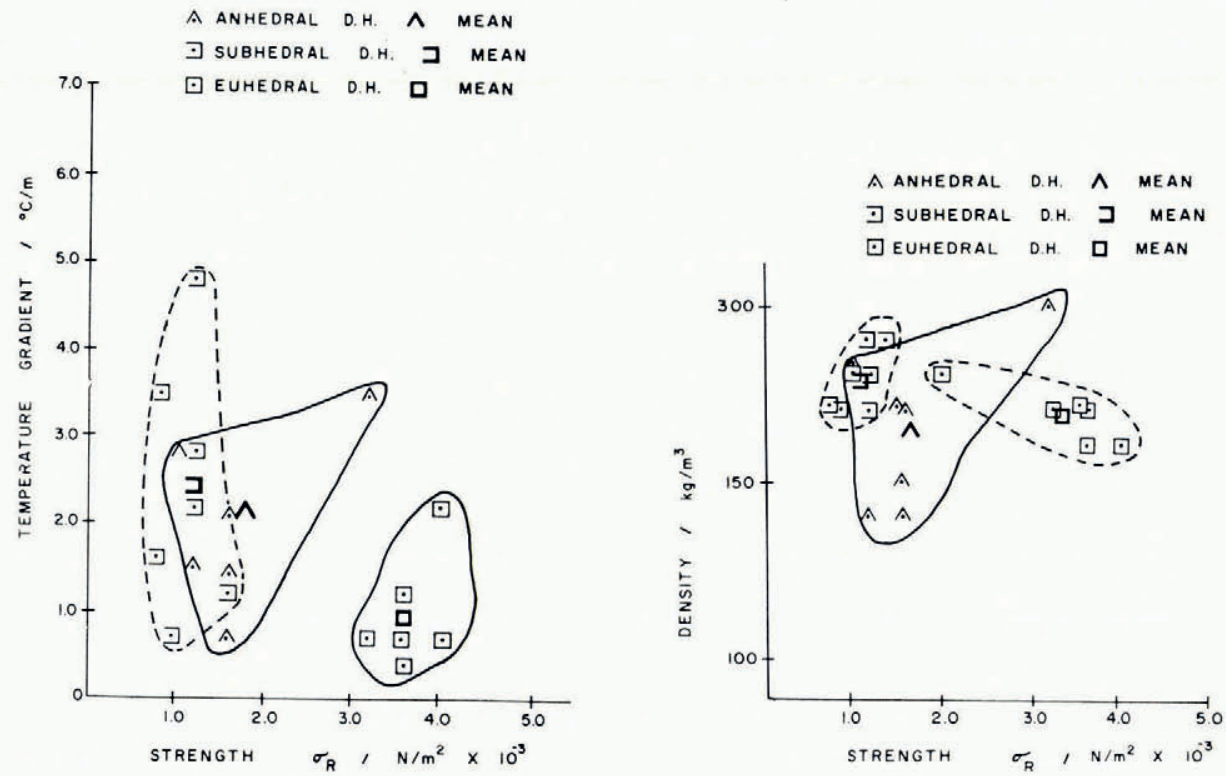

Fig. 3 (left). Graph showing the relationship between temperature gradient, strength, and crystal structure.

Fig. 4 (right). Graph showing the relationship between density, strength, and crystal structure.

Figures $\mathrm{I}$ and 2 show that in the $300 \mathrm{~mm}$ of snow pack, depth hoar was found through the first $200 \mathrm{~mm}$ of snow. At the time when measurement of these figures were made, the temperature was $-6.2^{\circ} \mathrm{C}$ on 18 December and $-13.8^{\circ} \mathrm{C}$ on 23 December 1974. These figures show also the interesting fact that the weakest snow is in the subhedral region and not in the euhedral snow. Note also the striking correlation between minimum strength, maximum temperature gradient, and local maximum density. This correlation raises some interesting questions concerning the process of heat flux through the pack and its relationship to strength and density. This will be discussed in more detail later. Figures 3 and 4 show the relationship between density, strength, and temperature gradient. Note that when snow type is classified by density and strength, or by temperature gradient and strength, the three types of snow fall into distinct regions as indicated by the Figures.

\section{LABORATORY INVESTIGATION}

Depth hoar was grown under laboratory conditions in an effort to study carefully the temporal variation of strength during the periods when the snow was subjected to temperature gradient metamorphism. Figure 5 illustrates the apparatus used to grow depth hoar. This apparatus, which was patterned after the experimental facility of Akitaya (1974), consists of a box insulated on all four vertical sides, heated on the bottom surface, and kept at cold-room temperature on the top surface. The bottom surface was held at $-\mathbf{I} \cdot 5 \pm 0.3^{\circ} \mathrm{C}$, a temperature which occurs characteristically at the bottom of typical snow-packs. The snow was cut into four identical rectangular columns of dimensions $10 \times 10 \times 40 \mathrm{~cm}^{3}$ and each column was placed inside four foam jackets.

When a test was begun one column was removed and cut into four $100 \mathrm{~mm}$ long specimens and then tested for strength and density. Each specimen was strength tested in an Instron testing machine by compressing it at a crosshead rate of $0.038 \mathrm{~m} / \mathrm{min}$ and thus measuring the stress at which fracture occurred. The density and crystal structure were also recorded for 

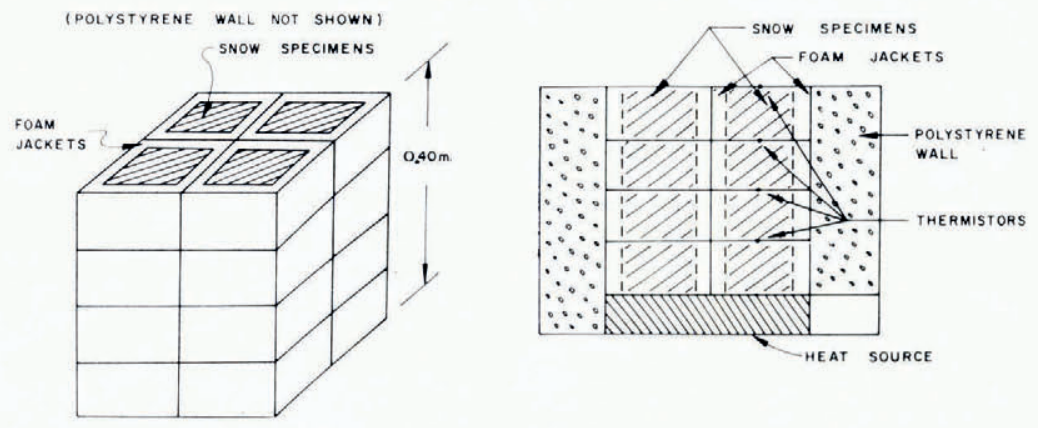

Fig. 5. The apparatus used in the depth-hoar experiment.

each specimen at this time. The other three specimens were placed in the depth-hoar apparatus and a solid foam insert was placed in the space which would have been occupied by the column previously tested. Then, the heating element at the bottom was turned on, thereby producing a heat flux up through the three columns in the apparatus. After four days a column was removed, cut into four specimens, and tested as above. This was repeated again at eight days and twelve days. The temperature was recorded at $100 \mathrm{~mm}$ increments by means of thermistors as illustrated in Figure 5 . The bottom two specimens became extremely fragile as time went on due to the metamorphism, but the foam jackets allowed these specimens to be handled without damage.

In all, about 8 experiments were run at various densities and temperature gradients. In all cases the original snow was fine-grained granular snow. For the sake of brevity, not all the 8 test results are illustrated in this paper. Figures 6 to 9 illustrate some of the typical test results. Figures 6 and 7 show the variation of snow strength with time in two tests. Figure 8 illustrates typical temperature profiles in the material. Figure 9 shows the variation of Young's modulus with time during three typical experiments. The drop in strength of the lower-density snow was invariably much sharper than the drop in material stiffness as indicated by the value of Young's modulus. Young's modulus was determined by measuring the slope of the load response curve for each fracture test. Assuming that the strain-rate was constant, the stress-rate then gave Young's modulus $E$ from the relationship

$$
E=\frac{\dot{T}}{\dot{e}}
$$

where $T$ is the axial stress, and $e$ is the axial strain. Since fracture occurred within a few seconds of the time the compression was started, this approximation was considered valid.
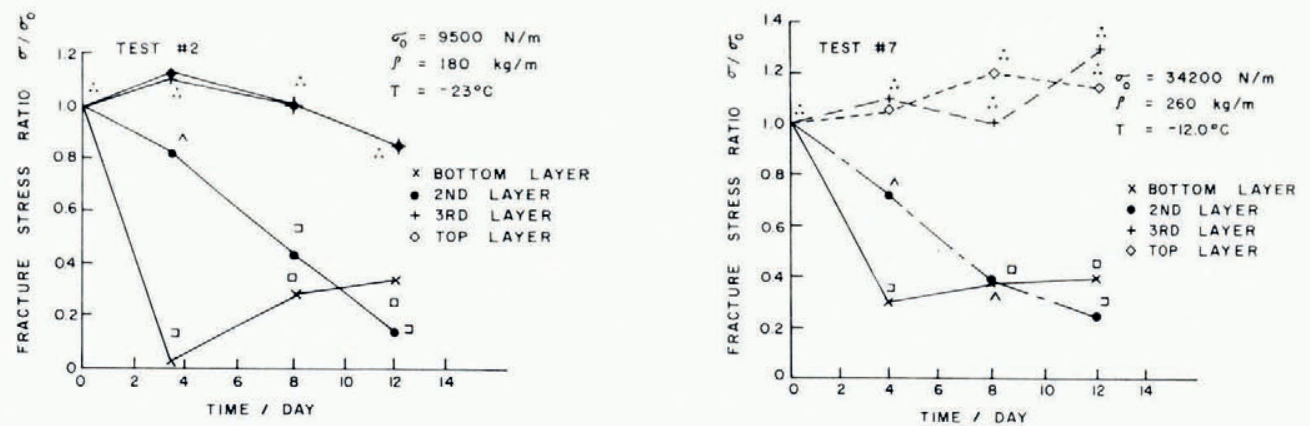

Fig. 6 (left) and Fig. 7 (right). Graphs showing the variation of fracture stress and crystal structure. 

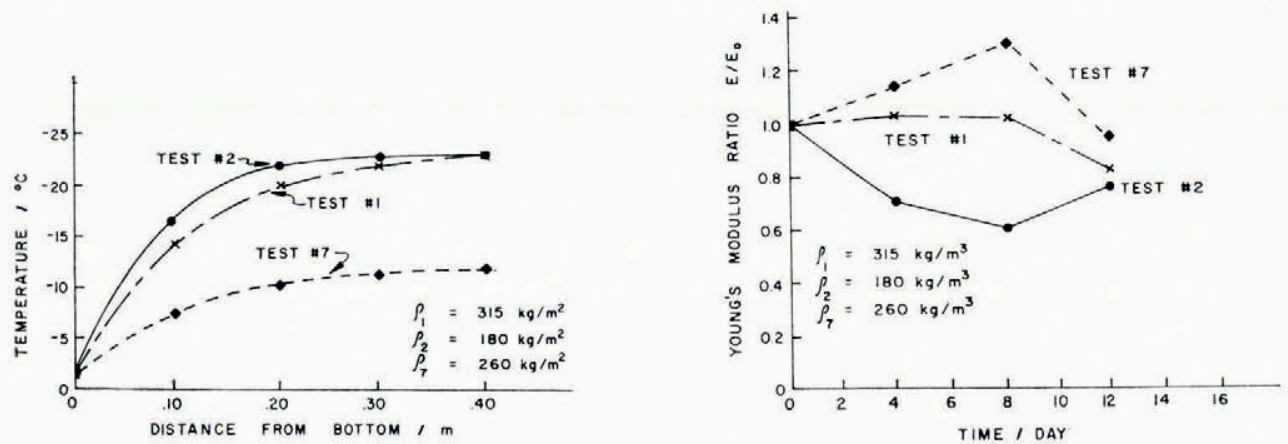

Fig. 8 (left). Steady-state temperature profiles.

Fig. 9 (right). Variation of Young's modulus with time during metamorphosis.

\section{Observations}

In the field investigation, the combination of thin snow cover and a period of cold weather produced an abundant quantity of depth hoar. Three well-defined zones of depth hoar appeared: euhedral, subhedral, and anhedral depth hoar. Both the whisk-broom abrasion tests and resistograph readings showed a definite band of weakness in the subhedral layer, whereas the fully metamorphosed euhedral snow was significantly stronger than the subhedral structure. This result was also verified in the laboratory experiments (Figs 6 and 7). For densities of $250 \mathrm{~kg} / \mathrm{m}^{2}$ or less, the strengthening invariably appeared in the laboratory experiments. The bottom layer would lose strength as it metamorphosed into the subhedral structure, and, as a fully developed euhedral stage was approached, the strength would begin to increase.

Usually, in the field tests, density was found to reach a local maximum at the weakest zone. This occurred in every test but one. Density readings taken in the laboratory were too inaccurate to verify the field results. By the time that the compression test was completed they had been damaged by the testing machine too extensively to allow an accurate measurement of density.

The temperature profile in nearly every case showed a marked increase in the temperature gradient at the weakest zone, as is clearly shown by Figures I and 2. This result was not verified by the laboratory studies. Figure 8 indicates that the temperature profile in the laboratory studies was well behaved with no indication of a local maximum in the temperature gradient. However, the spacing of the thermistors was $100 \mathrm{~mm}$, and consequently a small zone with a high temperature gradient may not have been detected in the laboratory. Note however the strong non-linearity of the temperature profile in the laboratory experiments, as indicated by Figure 8 . This result was also mentioned briefly by Akitaya (1974). In the field tests, the temperature in the anhedral and euhedral zones appeared also to have a similar non-linearity. However, the transient weather conditions in the field make a complete comparison difficult.

During the final period of observation in the field the pack exceeded $400 \mathrm{~mm}$ in depth, and the density and strength anomalies disappeared even though the three zones were still visible in the crystal texture. Throughout the period when the subhedral zone was extremely weak, the snow-pack had a strong tendency to collapse, this might account in part for the disappearance of the strength anomaly. Figures 3 and 4 show the strong correlation between snow type, density, temperature gradient, and strength, and also indicate that the three types of depth hoar can be grouped when plotted parametrically against two parameters.

One of the more striking results is illustrated in Figure 9 which depicts the time variation of Young's modulus during the temperature gradient metamorphism. Young's modulus 
never dropped to less than $50 \%$ of its original value in any of the experiments, whereas fracture stress in some of the experiments dropped to $10 \%$ of the original strength. It was also observed that in the laboratory experiments involving more dense snows (density greater than $\left.300 \mathrm{~kg} / \mathrm{m}^{3}\right)$, Young's modulus and the strength actually increased from the original values. In this case, "hard depth hoar" was found to form in much the same manner as described by Akitaya (1974).

\section{Conclusions}

In both field and laboratory experiments, temperature-gradient metamorphism has been observed to produce an advancing wave of change in the snow-pack. This wave, which moves upward from the ground level, initially weakens the snow as it metamorphoses from finegrained granular snow through anhedral depth hoar to the subhedral stage. At this point, the strength has reached a minimum. Under a continuing temperature gradient, the snow then undergoes further recrystallization and gradually strengthens until it reaches the euhedral depth-hoar stage. Apparently, the weakest zone in the pack is not fully-developed depth hoar, but is a zone of subhedral depth hoar directly above the euhedral zone.

The temperature gradient anomaly quite probably bears a close relationship to the metamorphic state of the snow. Heat flux through the pack, as indicated by Akitaya (1974), is due to two primary mechanisms: solid heat conduction through the snow, and sublimative heat exchange. The solid heat conduction is highly dependent upon the average crosssectional area of the bonds and necks connecting the grains in the crystalline structure. In the subhedral snow, which has little strength, these bonds necessarily are small and thereby decrease the effective thermal conductivity of the snow. In order to accommodate the heat flux supplied by the lower layers an increase in temperature gradient results, thus, locally increasing the heat flux due to both sublimative heat exchange and solid heat conduction.

The non-linear nature of the temperature profile observed in the laboratory experiment may also be explained in part by differences in thermal conductivity. Certainly the metamorphosed snow near the bottom had a lower thermal conductivity than the upper colder layers, since these upper layers remained practically invariant during the testing period. The strength, in Young's modulus, of these two layers retains its initial values during the experiments, implying that good intergranular bonding was maintained. Therefore, heat could be conducted more readily through these layers with relatively small temperature gradients.

One interesting observation is that the material stiffness (manifested in the Young's modulus) did not undergo any large decrease during the temperature gradient metamorphism; a variation was observed in the strength. While strength must be related, for the most part, to the load-bearing capacity of the grain bonds which occupy a relatively small portion of the material mass, Young's modulus must be determined by the deformation of the entire crystalline structure, i.e. the grain bodies as well as intergranular bonds. This would appear to indicate that the recrystallization does not radically affect the stiffness in the ice grains themselves.

\section{Acknowledgements}

The work reported in this paper was carried out under the joint sponsorship of the Office of Army Research-Durham (Grant No. DA-ARO-D-3I-I24-7I-GS9) and the National Science Foundation (Grant No. NSF GA-3943). The authors also wish to express their appreciation to Drs T. E. Lang and W. F. St. Lawrence for their many helpful comments during the research period. 


\section{REFERENGES}

Akitaya, E. 1965. Shimo-zarame-yuki no kenkyū. I [Studies of depth hoar. I]. Teion-kagaku: Low Temperature Science, Ser. A, [No.] 23, p. 67-74.

Akitaya, E. 1967[a]. Shimo-zarame-yuki no kenkyū. II [Studies of depth hoar. II]. Teion-kagaku: Low Temperature Science, Ser. A, [No.] 25, p. 37-47.

Akitaya, E. ${ }_{1967}[\mathrm{~b}]$. Some experiments on the growth of depth hoar. (In Oura, H., ed. Physics of snow and ice: international conference on low temperature science. ... I966. . . Proceedings, Vol. I, Pt. 2. [Sapporo], Institute of Low Temperature Science, Hokkaido University, p. 713-23.)

Akitaya, E. 1974. Studies on depth hoar. Contributions from the Institute of Low Temperature Science, Hokkaido University, Ser. A, No. 26.

Bradley, C. C. I966. The snow resistograph and slab avalanche investigations. Union de Géodésie et Géophysique Internationale. Association Internationale d'Hydrologie Scientifique. Commission pour la Neige et la Glace. Division Neige Saisonnière et Avalanches. Symposium international sur les aspects scientifiques des avalanches de neige, $5^{-10}$ avril 1965 , Davos, Suisse, p. 25 I-6o. (Publication No. 69 de l'Association Internationale d'Hydrologie Scientifique.)

Bradley, C. C. 1968. The resistograph and the compressive strength of snow. Fournal of Glaciology, Vol. 7, No. 51, p. 499-505.

Bradley, C. C., and Bowles, D. 1967. Strength-load ratio. An index of deep slab avalanche conditions. (In Oura, H., ed. Physics of snow and ice: international conference on low temperature science. . . 1966. . . Proceedings, Vol. I, Pt. 2. [Sapporo], Institute of Low Temperature Science, Hokkaido University, p. 1 243-53.)

Kojima, K. 1956. Sekisetsu-sō no nensei asshuku [Viscous compression of natural snow-layer. II]. Teion-kagaku: Low Temperature Science, Ser. A, [No.] i 5, p. I 1 7-35.

Seligman, G. 1936. Snow structure and ski fields; being an account of snow and ice forms met with in nature and $a$ study on avalanches and snowcraft. London, Macmillan and Co. [Reprinted, Jos. Adam, Brussels, ig62.]

\section{DISCUSSION}

R. A. Sommerfeld: Was your field temperature gradient measured at a single time? If so could your gradient be due to a thermal wave caused by the diurnal variation?

R. L. Brown: We are concerned about this. Our snow depth was only 0.3 to $0.4 \mathrm{~m}$, so even radiation effects may be important. We have discussed this observation, and feel that more experimental work is needed to clarify the curious temperature-gradient profile.

W. Good: I missed the point in the experimental testing: how do you define the different layers?

Brown: The snow columns were uniform initially but were cut into four sections for the tests.

M. R. DE Quervain: The development of a natural snow cover is greatly dependent on the conditions of deposit (amount of new snow deposit, temperature, etc.). Starting from these initial conditions the temperature gradient modifies the structure (constructive metamorphism) and the mechanical properties, but the initial conditions have to be quoted.

BRown: We had about $0.3 \mathrm{~m}$ of snow in one storm so about two-thirds of the total snow depth accumulated from this one storm.

DE Quervain: I do not mind subdividing the classification of depth hoar (as was also done extensively by H. P. Eugster in 1950) but the symbols adopted in the International Snow Classification should be avoided (square $=$ full faceted crystals; angle $=$ depth hoar as a whole).

BRown: I was not aware of these standards. 